\title{
GAMBARAN KARAKTERISTIK KADER POSYANDU DI DESA CIKUNIR KECAMATAN SINGAPARNA KABUPATEN TASIKMALAYA TAHUN 2012
}

Oleh :

\author{
Sinta Fitriani, S.KM,MKM
}

\section{A. Abstrak}

Cakupan D/S sebesar 39,20\%, cakupan K/S $100 \%$, dan cakupan N/S 26,47\% . Pencapaian indikator Posyandu di Desa Singaparna tidak terlepas dari peran kader posyandu yang ada di desa tersebut. Bertitik tolak dari latar belakang tersebut, maka penulis merasa tertarik untuk mengetahui gambaran karakterisrik kader Posyandu di Desa Cikunir Kabupaten Tasikmalaya tahun 2012. Tujuan dari penelitian ini adalah Untuk mengetahui dan memperoleh Gambaran Karakteristik Kader Posyandu di Desa Cikunir Kabupaten Tasikmalaya tahun 2012.

Jenis penelitian ini menggunakan metoda deskriptif. Populasi dalam penelitian ini adalah seluruh kader Posyandu aktif di Desa Cikunir wilayah kerja Puskesmas Singaparna Kabupaten Tasikmalaya sebanyak 49 orang (periode April 2012). Tehnik pengambilan sampel dengan total sampling. Instrumen yang digunakan adalah kuesioner. Analisis data yang dilakukan pada penelitian ini menggunakan analisis univariat.

Hasil penelitian didapatkan bahwa Pendidikan kader posyandu mayoritas lulus SD (47\%) dan yang tidak tamat SD (2\%). Mayoritas kader posyandu sebagai ibu rumah tangga (78\%). Sebanyak $98 \%$ Kader posyandu mendapat kesempatan mengikuti Pelatihan $98 \%$ pelatihan. Fasilitas Posyandu yang masih kurang memadai. Lama kerja kader Posyandu mayoritas lebih dari 3 Tahun (65\%). Tingkat Pengetahuan kader mayoritas kategori baik (88\%), serta 97,96\% kader mendapat Imbalan.

Berdasarkan pembahasan hasil penelitian, penulis mengambil kesimpulan dan saran-saran sebagai berikut : Pendidikan kader, kader posyandu berpendidikan ada yang paling banyak lulus SD (47\%) dan yang tidak tamat SD (2\%). Mayoritas kader posyandu sebagai ibu rumah tangga (78\%). Sebanyak $98 \%$ Kader posyandu mendapat kesempatan mengikuti Pelatihan $98 \%$ pelatihan. Fasilitas Posyandu yang masih kurang memadai. Lama kerja kader Posyandu mayoritas lebih dari 3 Tahun (65\%). Tingkat Pengetahuan kader mayoritas kategori baik (88\%), serta 97,96\% kader mendapat Imbalan. Sehingga peneliti menyarankan aparatur desa harus selalu diikutsertakan dalam pembinaan maupun bimbingan teknis sehingga kader termotivasi untuk meningkatkan perannya dalam kegiatan posyandu

Kata Kunci : Kader posyandu, tingkat pendidikan, lama bekerja, pengetahuan serta imbalan 


\section{B. Latar Belakang}

Salah satu wujud peran serta masyarakat dalam pembangunan kesehatan adalah Pos Pelayanan Terpadu (Posyandu). Posyandu merupakan pusat kegiatan masyarakat dibidang Keluarga Berencana dan kesehatan yang dapat dikembangkan berdasarkan pendekatan yang kekuatannya terletak pada pelayaanan kesehatan dasar, kerjasama lintas sektoral dan peran serta masyarakat. Salah satu hasil kegiatan Posyandu yang dapat dijadikan Indikator partisipasi masyarakat adalah cakupan D/S. Cakupan D/S adalah jumlah sasaran balita yang ditimbang di Posyandu di bandingkan dengan jumlah sasaran balita.

Salah satu Desa di wilayah Kerja Puskesmas Singgaparna yang telah

\section{Metode}

Jenis penelitian ini menggunakan metoda deskriptif, untuk memperoleh gambaran karakteristik kader posyandu di Desa Cikunir wilayah kerja UPT Puskesmas Singaparna Kabupaten Tasikmalaya Tahun 2012.

Populasi dalam penelitian ini adalah seluruh kader Posyandu aktif di Desa Cikunir wilayah kerja Puskesmas Singaparna Kabupaten Tasikmalaya sebanyak 49 orang (periode April 2012). Tehnik pengambilan sampel dengan total sampling.

Instrumen yang digunakan adalah kuesioner untuk mengukur pengetahuan kader mengenai pengertian, tujuan, sasaran dan program posyandu.

Pengolahan data dilakukan melalui tahapan sebagai berikut:

1. Editing, merupakan kegiatan untuk melakukan pengecekan isian formulir atau kuesioner apakah jawaban yang ada sudah lengkap dan jelas. memiliki indikator kegiatan Posyandu cukup bagus adalah Desa Cikunir yang memiliki 8 Posyandu dengan jumlah kader aktif sebanyak 49 orang. Cakupan D/S sebesar 39,20 \%, cakupan K/S 100 $\%$, dan cakupan N/S 26,47 \% .

Pencapaian indikator Posyandu di Desa Singaparna tidak terlepas dari peran kader posyandu yang ada di desa tersebut. Bertitik tolak dari latar belakang tersebut, maka penulis merasa tertarik untuk mengetahui gambaran karakterisrik kader Posyandu di Desa Cikunir Kabupaten Tasikmalaya tahun 2012.

Tujuan dari penelitian ini adalah Untuk mengetahui dan memperoleh Gambaran Karakteristik Kader Posyandu dan Pencapaian Indikator Posyandu di Desa Cikunir Kabupaten Tasikmalaya tahun 2012.

2. Coding, merupakan kegiatan perubahan data berbentuk huruf menjadi data berbentuk angka atau bilangan.

3. Proccessing, setelah semua kuesioner terisi penuh dan benar serta telah melalui tahapan pengkodean, maka langkah selanjutnya adalah memproses data agar dapat dianalisis. Pemrosesan data dilakukan dengan cara meng-entry data dari kuesioner ke paket program komputer. Program yang digunakan untuk pemrosesan data adalah program Microsoft Exel dan SPSS versi 13,0.

4. Cleaning, merupakan kegiatan pengecekan kembali data yang sudah dientry apakah ada kesalahan atau tidak.

Analisis data yang dilakukan pada penelitian ini menggunakan analisis univariat. Analisi univariat dilakukan untuk mendeskripsikan masing-masing variabel yang digunakan dalam penelitian ini dengan melihat distribusi frekuensi dengan ukuran prosentase/ proporsi pada setiap variabel yang diteliti. 


\section{Hasil Penelitian}

Survei terhadap kader Posyandu di Desa Cikunir wilayah kerja Puskesmas Singaparna dilakukan dengan menggunakan instrumen Kuesioner. Jumlah seluruh responden yang diambil sebanyak 49 orang kader. Variabel-variabel yang diteliti meliputi pendidikan, pekerjaan, lama waktu menjadi kader, pengetahuan, pelatihan yang diikuti, studi banding, dan imbalan. Hasilnya adalah sebagai berikut.

\section{Pendidikan}

Hasil penelitian menunjukkan bahwa kader memiliki tingkat pendidikan yang berbeda hal ini dapat dilihat berikut ini :

\begin{tabular}{|c|l|c|c|}
\hline No. & $\begin{array}{c}\text { Pendidikan } \\
\text { Terakhir }\end{array}$ & Frekuensi & \% \\
\hline 1 & Tidak tamat & 1 & 2,0 \\
2 & SD & 23 & 47,0 \\
3 & Tamat SD & 11 & 23,0 \\
4 & Tamat SMTP & 15 & 30,0 \\
5 & Tamat SMTA & 0 & 0 \\
& Tamat PT & & \\
& (Perguruan & & \\
& Tinggi) & & \\
\hline \multicolumn{2}{|c|}{ Total } & 49 & 100,0 \\
\hline
\end{tabular}

Dari tabel tersebut dapat diketahui bahwa kader Posyandu di Desa Cikunir ada yang tidak tamat Sekolah Dasar berjumlah $2 \%$, dengan tingkat pendidikan yang lulusan Sekolah Dasar berjumlah $47 \%$ dari semua kader yang ada, diikuti oleh kader yang lulusan pendidikan SMTP dengan jumlah $23 \%$, dan lulusan SMTA sebanyak $30 \%$.

\section{Pekerjaan}

Distribusi Frekuensi Kader Menurut Pekerjaan Di Desa Cikunir Wilayah Puskesmas Singaparna Tahun 2012.

\begin{tabular}{|c|l|c|c|}
\hline No. & Pekerjaan & Frekuensi & \% \\
\hline 1 & Petani & 9 & 18,00 \\
2 & Ibu & 39 & 78,00 \\
3 & Rumah & 0 & 0,00 \\
4 & Tangga & 1 & 2,0 \\
5 & PNS & 1 & 2,00 \\
& Pegawai & & \\
& Swasta & & \\
& Lain-lain & & \\
\hline \multicolumn{2}{|c|}{ Total } & 49 & 100,0 \\
\hline \multicolumn{2}{|l}{} \\
\hline
\end{tabular}

Dari tabel diatas dapat kita lihat bahwa sebagian besar kader yang berada di Desa Cikunir mempunyai pekerjaan sebagai Ibu Rumah Tangga yaitu sebesar $78 \%$, petani $18,0 \%$, Pegawai Negeri Sipil tidak ada, Pegawai Swasta dan lain-lain masing-masing $2 \%$.

\section{Pelatihan}

Distribusi Frekuensi Kader Menurut Kesempatan Dalam Pelatihan Wilayah Puskesmas Singaparna Tahun 2012

\begin{tabular}{|c|l|c|c|}
\hline No. & Pelatihan & Frekuensi & \% \\
\hline 1 & Pernah & 48 & 98,0 \\
2 & Tidak & 1 & 2,00 \\
& Pernah & & \\
\hline \multicolumn{2}{|c|}{ Total } & 49 & 100,0 \\
\hline
\end{tabular}


Dari tabel tersebut diterangkan bahwa 98,0 \% kader pernah mendapatkan pelatihan, yaitu pelatihan dasar 98,0\%, Pelatihan kemampuan menggerakkan masyrakat 2,0 \% . Kader yang pernah mengikuti pelatihan dapat meningkatkan pengetahuan kader sebagai penggerak masyarakat dan yang tidak pernah mengikuti pelatihan kemungkinan lama aktif / partisipasi kader dapat dilihat pada tabel berikut :

\section{Lama Menjadi Kader}

Distribusi Frekuensi Kader Menurut Masa Kerja di Desa Cikunir Wilayah Kerja Puskesmas Singaparna Tahun 2012

\begin{tabular}{|c|l|c|c|}
\hline No. & $\begin{array}{c}\text { Lama } \\
\text { aktif/Partisipasi }\end{array}$ & Frekuensi & \% \\
\hline 1. & Kurang dari 1 & 3 & 6,0 \\
2 & tahun & 14 & 29,0 \\
3. & $1-3$ Tahun & 32 & 65,0 \\
& Lebih dari 3 & & \\
& Tahun & 49 & 100,0 \\
\hline \multicolumn{2}{|l}{} \\
\hline
\end{tabular}

Dari tabel tersebut dapat diketahui bahwa kader Posyandu di Desa Cikunir ada yang masa kerjanya masih kurang atau paling sedikit dalam 1 Tahun berjumlah $6 \%$, yang masuk cukup masa kerjanya 1 - 3 Tahun berjumlah $29 \%$ dari semua kader yang ada, dan yang paling banyak kader yang masa kerjanya lebih dari 3 Tahun yaitu sebanyak 65 $\%$ dari kader yang ada di Desa Cikunir

Dari sejumlah Kader Posyandu yang lama kerjanya kurang dari 3 Tahun tidak sampai $50 \%$, dan pada umumnya kader sudah mempunyai masa kerja lebih dari 3 Tahun dan mempunyai pengetahuan lebih luas lama cara pelayanan di posyandu yang berada di Desa Cikunir wilayah kerja UPT.Puskesmas Singaparna

\section{Pengetahuan}

\begin{tabular}{|c|c|c|c|c|c|c|c|c|}
\hline $\begin{array}{l}\mathbf{N} \\
\mathbf{0}\end{array}$ & Pengetahuan Kader & $\begin{array}{c}\text { Tah } \\
\mathbf{u}\end{array}$ & $\%$ & $\begin{array}{c}\text { Tida } \\
\mathbf{k} \\
\text { tahu }\end{array}$ & $\%$ & $\begin{array}{c}\text { Kate } \\
\text { gori }\end{array}$ & $\begin{array}{l}\text { Total } \\
\text { kader }\end{array}$ & $\%$ \\
\hline 1. & Kepanjangan Posyandu & 48 & 98 & 0 & 0 & Baik & 49 & 100 \\
\hline 2. & Tujuan kegiatan posyandu & 48 & 98 & 1 & 2 & Baik & 49 & 100 \\
\hline 3. & Yang menjadi sasaran & 49 & 10 & 0 & 0 & Baik & 49 & 100 \\
\hline 4. & Posyandu & 49 & 0 & 0 & 0 & Baik & 49 & 100 \\
\hline 5 . & Yang menjadi program & 49 & 10 & 0 & 0 & Baik & 49 & 100 \\
\hline 6. & kegiatan & 44 & 0 & 5 & 10 & Baik & 49 & 100 \\
\hline 7. & Sistem pelaksanaan kegian & 28 & 10 & 21 & 43 & Kurang & 49 & 100 \\
\hline 8. & kader & 49 & 0 & 0 & 0 & Baik & 49 & 100 \\
\hline 9. & Kegiatan yang dilakukan di & 44 & 90 & 5 & 10 & Baik & 49 & 100 \\
\hline 10 & meja ke 4 & 43 & 57 & 6 & 12 & Baik & 49 & 100 \\
\hline & Penimbangan dilakukan di & & 10 & & & & & \\
\hline & meja ke... & & 0 & & & & & \\
\hline & Salah satu tugas kader & & 90 & & & & & \\
\hline & posyandu & & 88 & & & & & \\
\hline & $\begin{array}{l}\text { Yang bukan termasuk sasaran } \\
\text { posyandu }\end{array}$ & & & & & & & \\
\hline & $\begin{array}{l}\text { Wujud tercapainya tujuan } \\
\text { posvandu }\end{array}$ & & & & & & & \\
\hline
\end{tabular}


Dari tabel tersebut dapat diketahui bahwa kader Posyandu di Desa Cikunir mengenai pengetahuan tentang pengertian kepanjangan posyandu 98 $\%$,tujuan kegiatan posyandu $98 \%$,yang menjadi sasaran posyandu $100 \%$, yang menjadi program kegiatan posyandu 100 $\%$,sistem pelaksanaan kegiatan kader posyandu, kegiatan yang dilakukan di meja ke empat $90 \%$, penimbangan dilakukan di meja $57 \%$, salah satu tugas kader posyandu $100 \%$, yang bukan termasuk sasaran posyandu $44 \%$ dan wujud tercapainya posyandu mencapai $88 \%$ dari semua kader yang ada, di Desa Cikunir Wilayah Puskesmas Singaparna.

Dilihat dari segi pengetahuan kader Posyandu mengenai sarana dan prasarananya masih kurang maka dalam melaksanakan pelayanan kurang teratur menurut urutan kegiatan pada waktu hari Poyandu masih ada hambatan atau kesulitan , karena sistem lima meja dalam Posyandu belum sepenuhnya dilaksanakan, dari meja I sampai dengan meja 4 semua dilakukan oleh kader Posyandu dan meja 5 pelayanan oleh tenaga kesehatan meliputi : pelayanan KIA, KB, Imunisasi dan Pengobatan sederhana. Dr Zulkifli,SKM

Fakultas Kesehatan Masyarakat USU (2003). Selain pengetahuan tersebut pada umumnya bisa dikatakan baik dan mengenai studi banding kader bisa dilihat pada tabel berikut :

\section{Imbalan}

\section{Distribusi Frekuensi Kader dalam menerima imbalan Kader Posyandu di Desa Cikunir Wilayah Kerja Puskesmas Singaparna} Tahun 2012

\begin{tabular}{|c|l|c|c|}
\hline No & Imbalan & $\begin{array}{c}\text { Frekuen } \\
\text { si }\end{array}$ & \% \\
\hline 1. & Ya & 48 & 97,96 \\
2 & Tidak & 1 & 2,04 \\
\hline \multicolumn{2}{|c|}{ Total } & 49 & 100,0 \\
\hline
\end{tabular}

Dari tabel tersebut dapat diketahui bahwa kader Posyandu di Desa Cikunir yang pernah menerima imbalan mencapai 97,96 \% dan yang tidak pernah menerima imbalan mencapai 2,04 \% dari semua kader Posyandu yang

\section{E. Pembahasan}

Karakteristik kader Posyandu

a. Pendidikan kader

Berdasarkan tabel dapat diketahui bahwa seluruh kader Posyandu yang diambil sebagai sampel, yang berpendidikan tidak tamat SD $2 \%$, berpendidikan SD $47 \%$, SMTP $23 \%$ dan SMTA $30 \%$. Hal ini menunjukkan bahwa seluruh kader yang ada memenuhi syarat yang dinyatakan dalam ada di Desa Cikunir Wilayah Puskesmas Singaparna. Dalam melaksanakan tugasnya, seorang kader Posyandu tidak terlepas dari hambatanhambatan dan masalah-masalah yang dihadapi.

buku peran serta masyarakat Dep Kes RI bahwa persyaratan bagi seorang kader diantaranya adalah dapat membaca dan menulis huruf latin walaupun tidak tamat SD serta dapat berbahasa Indonesia. Bagi kader tidak lulus SD yang penting sudah dapat membaca, menulis dan berbahasa indonesia. Pengetahuan kader bisa diperoleh dari latihan kader atau dari media masa elektronik maupun dari media cetak. 
Latar belakang pendidikan kader semakin tinggi dapat membantu peningkatan dalam pelayanan kader diposyandu.

b. Pekerjaan kader

Disamping hasil tersebut diatas, juga dinyatakan bahwa untuk seorang kader setidaknya masih cukup mempunyai waktu bekerja untuk mencari nafkah. Hal ini dapat dilihat pada tabel 5.4 bahwa sebagian besar kader Posyandu yang ada di wilayah kerja Puskesmas Singaparna I mempunyai pekerjaan petani $18 \%$, ibu rumah tangga $78 \%$, PNS $0,00 \%$ dan Pegawai Swasta $2 \%$ dan lain-lain sebanyak $2 \%$. Sebagian besar kader tidak bekerja sehingga kader dapat memiliki waktu yang lebih leluasa untuk melakukan tugasnya untuk melayani masyarakat. Pekerjaan kader yang dalam pennghasilan nya cukup untuk menopang kebutuhan hidup sangat berpengaruh pada kinerja dan semangat kader dalam berperan di posyandu karena kader merasa tida terbebani dalam bertugas sebagai kader.

\section{c. Pelatihan Kader}

Guna memper lancar posyandu semua kader posyandu di beri kesempatan untuk mengikuti pelatihan, yang pernah mengikuti pelatihan dilihat dari tabel 5.5 diterangkan bahwa 98,0 \% kader pernah mendapatkan pelatihan, yaitu pelatihan dasar 98,0\%, Pelatihan kemampuan menggerakkan masyakat $2,0 \%$. Pelatihan kader biasanya diselenggrakan oleh lembaga kesehatan atau lembaga pemertintahan dibidang penggerakan sosial masyarakat, pelatihan kader kesehtan, kader Gizi keluarga dan pelatihan kader desa siaga

d. Lama Kerja

Berdasarkan hasil penelitian dilihat dari tabel 5.6 tersebut dapat diketahui bahwa kader Posyandu di Desa Singaparna ada yang masa kerjanya masih kurang 1 Tahun berjumlah $6 \%$, yang masa kerjanya $1-3$ Tahun berjumlah $29 \%$ dari semua kader yang ada, dan kader yang masa kerjanya lebih dari 3 Tahun sebanyak $65 \%$. Kader Posyandu yang masa kerjanya lebih dari 3 tahun sudah lebih memahami dalam melaksanakan kegiatan posyndu terutam bekerja yang memakai sistem lima meja bila dibadingkan dengan kader yang masa kerjanya kurang dari tiga tahun

e. Pengetahuan

Dilihat dari tabel 5.7 tersebut dapat diketahui bahwa kader Posyandu di Desa Cikunir walaupun masih ada yang belum tamat SD ternyata dalam hasil penelitian mengenai pengetahuan boleh dikatakan baik dengan alasan semua kader bisa mengisi angket yang telah kami berikan, tentang pengertian kepanjangan posyandu $98 \%$, tujuan kegiatan posyandu $98 \%$,yang menjadi sasaran posyandu $100 \%$, yang menjadi program kegiatan posyandu 100 $\%$,sistem pelaksanaan kegiatan kader posyandu, kegiatan yang dilakukan di meja ke empat $90 \%$, penimbangan dilakukan di meja ke dua $57 \%$, salah satu tugas kader posyandu $100 \%$, yang bukan termasuk sasaran posyandu $44 \%$ dan wujud tercapainya posyandu mencapai $88 \%$ dari semua kader yang ada, di Desa Cikunir Wilayah Puskesmas Singaparna

f. Imbalan

Dari tabel tersebut dapat diketahui bahwa kader Posyandu di Desa Cikunir yang pernah menerima imbalan mencapai 97,96 \% dan yang tidak pernah menerima imbalan mencapai 2,04 \% dari semua kader Posyandu yang ada di Desa Cikunir Wilayah Puskesmas Singaparna. 


\section{F. Simpulan dan saran}

Berdasarkan pembahasan hasil penelitian, penulis mengambil kesimpulan dan saran-saran sebagai berikut : Pendidikan kader, kader posyandu berpendidikan ada yang paling banyak lulus SD (47 \%) dan yang tidak tamat SD (2 \%). Mayoritas kader posyandu sebagai ibu rumah tangga (78 $\%)$. Sebanyak $98 \%$ Kader posyandu mendapat kesempatan mengikuti Pelatihan $98 \%$ pelatihan. Fasilitas

\section{G. Referensi}

Depkes RI, 2011, Pedoman Kegiatan Kader Posyandu, Jakarta.

Depkes RI, 2000, Partisipasi Masyarakat Dalam Bidang Kesehatan, Jakarta.

Depkes RI, 2010, Pedoman Kerja Puskesmas Jilid IV, Jakarta.

Mantra, I. B.,2010, Pedoman Penyuluhan Kesehatan Masyarakat bagi Petugas Puskesmas, Jakarta.

Depkes RI, 2010, Peningkatan Peran Serta Masyarakat Dalam Kegiatan Posyandu,Jakarta

Depkes RI, 1994 Arrif Pedoman Manajemen Peran Serta Masyarakat, Jakarta

Depkes RI, 1995, Pedoman Manajemen Peran Serta Masyarakat Pembangunan Kesehatan, Jakarta.Depkes RI, 2000, Buku Panduan Pengelolaan Program Perbaikan Gizi Kabupaten/Kota
Posyandu yang masih kurang memadai. Lama kerja kader Posyandu mayoritas lebih dari 3 Tahun $(65 \%)$. Tingkat Pengetahuan kader mayoritas kategori baik (88 \%), serta 97,96\% kader mendapat Imbalan.

Sehingga peneliti menyarankan aparatur desa harus selalu diikutsertakan dalam pembinaan maupun bimbingan teknis sehingga kader termotivasi untuk meningkatkan perannya dalam kegiatan posyandu.

Depkes RI, 2001, Pendekatan Kemasyarakatan, Jakarta.

Dinkes Jawa Barat , 2002, Pedoman Promosi Posyandu, Bandung.

Departemen Kesehatan dan Kesejahteraan Sosial 2000 Buku Kader Usaha Perbaikan Gizi Keluarga.

Irfan Islamy, M., 2002, Kebijakan Publik, Universitas Terbuka, Jakarta.

Manasse Malo, 2002, Metode Penelitian Sosial, Universitas Terbuka, Jakarta.

Dinkes Kabupaten, 2007, Profil Kesehatan,

Tasikmalaya.Puskesmas, 2007, Profil Kesehatan, Singaparna

Dr.Ina Hernawati,MPH, 2007 Pedoman Pemantauan Wilayah SetempatGizi (PWS- GIZI) Direktur Bina Gizi Masyarakat (Depkes RI), Jakarta 